\title{
An Exploration of "Eurocommunism"
}

\author{
Sun Ping \\ Ideological and Political Teaching Department, North China Electric Power University, Beijing China \\ sp@ncepu.edu.cn
}

\begin{abstract}
Eurocommunism", which was founded in the 1950s, has produced great influences on the International Communism Movement. The understanding of this important contemporary trend of thought provides a great reference for the building up of socialist modernization.

Index Terms - Eurocommunism, exploration, influence

In the late years of the 1970s, "Eurocomminism", proposed by the Italian Communist Party and responded by the French and Spainish Communist Parties, drew the great attention of the whole world and became a powerful political trend of thought, pushing the Communist Parties of the European developed countries to the front of the political stage. However, in the early years of the 1980s, the Communist Parties advocating "Eurocommunism" were frustrated more or less, so the once fashinable "Eurocommunism" did not achieve the expected results in practice. Therefore, this paper attempts to analyze the following aspects: What trend of thought "Eurocommunism" is? How is it developed? What functions does it provide in the process of history?
\end{abstract}

\section{The History and Theory of "Eurocommunism"}

"Eurocommunism", different from that of the Soviet Union, is a socialist road or model proposed by some of the Communist Party members in the developed countries on the basis of their own country's social reality. It is originated from the "Positional Warfare" by Gramsci in the 1920s, but it is not further developed because of the change of the international situation and the interference of the Soviet Union's Communist Party.

Since the "Twentieth National Congress of the Communist Party of the Soviet Union" in the 1950s and the decreasing blind worship of "Stalin Model", the Communist Party members in the European developed countries began to seek a different road from the Soviet Union or the Sociodemocratic. In March, 1977, the Communist Party leaders of Italy, France and Spain, Enrico Belinguer, Georger Marchais and Santiago Carrillo met in Madrid, made a joint statement, the so-called "Declaration of Eurocommunism". This meeting and the joint statement are regarded as the symbol of "Eurocommunism", the embodyment of their theoretical explorations.

"Eurocommunism" was put forward by the socialist theorist, Enrico Belinguer, the former Italian secretarygeneral. Its guiding principles are the following: to wrest state power by democracy instead of violence; to reform but not abolish the state apparatus; to establish the Multiparty Alliance, with the Communist Party as the political center; to establish the wide alliance of the democratic power and the progressive power, instead of the alliance of workers and peasants. "Eurocommunism" admits the guiding ideology of Marxism and the organizing principle of democratic centralism, taking communism as its final goal. At the same time, it keeps the previlege of using violence in special situations, like the situations when democracy and freedom are lost. It holds the view that to realize socialism, a "Special Democratic Road" is inevitable, that is, implementing people's democratic revolution to realize economic, political and socialist democracy, with socialism revolution as its final goal. It emphasizes that Marxism must be combined with the respective situations of the countries, and every country should find its unique way of development. Comparatively speaking, "Eurocommunism" involves more theoretical elements than "Democratic Socialism" and "General Socialism". The party proposing "Eurocommunism" makes every effort in the following three aspects both theoretically and practically.

First, it is required to shake off the control and fetters of the Communist Party of the Soviet Union so as to gain the right of policy decision. The Communist Parties in the developed countries of Europe were mostly founded under the leadership of Lenin, and by this guiding ideology they led their working people to fight against capitalism, and they also played a significant role in the anti-fascism in World War II. But since the Cold War of 1947, the Communist Party of the Soviet Union began to show arrogance over the other small Parties in the International Communism Movement, strengthened the control over the European Communist Parties, and forced them to follow their way. After the 1960s, the politics and economy of the capitalist countries changed a great deal, and the situation urged the Communist Parties of the different countries in Europe to understand the real circumstances of capitalism and seek their own appropriate way. The twentieth Congress of the Communist Party of the Soviet Union and the Sino-Soviet polemic propelled the European Communist Parties to seek their own specific ways. At the same time, the masses in the countries were unsatified with their own party's blind worthship of the Soviet Union, and this dissatisfaction increased with time. Some of the voters even called their Communist Party as "the Party of Foreign Nationalism", because the Party was devoted to the Soviet Union instead of its own country and nation. In order to resume their image and win over the votes, the Communist Party of every country saw the necessity of getting rid of the control of the Soviet Union and carrying out the policy of independent strategy. Therefore, the countries proposing 
"Eurocommunism" adopted independent policies and even expressed their criticism of the Soviet Union, for example, they blamed the "human rights" in the Soviet Union, and condemned their action of sending soldiers into Cambodia in the late years of 1970 s.

Secondly, it is necessary to explore a peaceful democratic way to socialism. "Eurocommunism" holds the view that if the developed countries want to transform to socialism, they cannot seize the power by armed force just as the Bolshevism of Russia did, they must follow the peaceful democratic way, especially the rooted democracy tradition of the western countries. Just as Carrillo (1982) said, according to the Constitution, the western countries have a rooted tradition of democracy and they can carry out the democratic socialism transformation. Violence is not only unreasonable but also unrealistic. Marchais (cited in Wilson 1993: 69) once pointed out "In France, democracy is the convenient road to socialism". So these Communist Parties started to re-comment on the Capitalist Parliament Democracy. Lenin regarded Capitalist Parliament Democracy as hypocratic and took it as a form of dictatorship by the capitalists. But most of the Parties believe "Eurocommunism" changed their attitudes towards Leninism which they adhered to for so many years, holding the view that Communist Party comes to power through Congress Democracy and general election. Simultaneously, they began to have fresh ideas of those capitalist countries, believing that the contemporary developed capitalist countries possess some new characteristics. State is no longer the tool used by the capitalists to control the oppressed, and Lenin's state theories could no longer explain the situation of the contemporary developed capitalist countries. To them, the organizations of modern capitalist countries changed a lot and the functions of the countries were broadened. So state is a neutral term for class struggle and a management tool over every class. Although state has the function of ruling, its management function gains more and more importance. Its function of social management appeals to all in the society. Therefore, the task of the Communist Party is not to destroy the state but to carry out the democracatic reform by the structural readjustment, so as to make it possess more new shapes. By general election, the Communist Party comes to political power and starts to build socialism.

And the third effort is to explore models of socialism with their respective specific characteristics. "Eurocommunism" holds that there is no fixed model of socialism, and after demolishing the capitalist power the workers in the developed countries should carry out "the special democratic socialist model". Advocating "Eurocommunism", every Communist Party should study their own situation and put out their own socialist road and model. For example, the Communist party of France proposed the "socialism with French characteristics", on which Marchais once gave a clear explanation, pointing out that there is no common model of socialism, the socialism of France is not something borrowed from foreign countries, made in foreign countries and then given different colours, or grafted onto the branches of the native trees, and the socialism that the people of France want must be democratic and full of French characteristics. Generally speaking, the socialism that "Eurocommunism" proposed has the following features: its economic mechanism is a "new economic model", in which the public ownership is dominant but various systems of ownership also exist; its political power prefers a high degree of political democratic society, with "leadership by the workers" instead of "proletarian dictatorship", aiming to form a state in which the workers are the dominant group, the alliance of the strength of work and culture is the main leadership, and the masses of people are the major support; its system of leadership is mainly a system of multiparties, that is, every party follows the democratic principle according to the Constitution of Democracy, and then through general election they reach the internationalism. Without the differences and independence of every socialist country and every Communist Party, there is no real internationalism. Every party should be equal and independent, showing respect to every other country, exercising equal power, and not interfering with each other's affairs.

\section{The essence and historical significance of "Eurocommunism"}

At the high tide of "Eurcommunism" in the late years of 1970s, its influence passed over Europe and there came an enthusiam for it all over the world. At that time, 14 countries of Europe claimed a firm belief of "Eurocommunism", and the Communist Parties of some of the non-European countries, such as Japan, Australia, Mexica also expressed their sincere support for its theory. In its prime, the number of firmbelievers among the Communist Party members in the developed countries all over the world is 3,300,000 million, over $75 \%$ of all the members of the Communist Party in those capitalist countries, taking more than 300 seats in Parliament, and some of the leaders even held an important position in their government. It was expected that the high tide of "Eurocommunism" would produce such a huge practical effect that it will finally change the International Communism Movement to a great extent. However, its development was out of people's expectation. "Eurocommunism", so to speak, was full of hidden crisis after its formation and its theoretical thoughts had obvious shortcomings and even complete wrongness.

First, the formation and development of "Eurocommunism" theories, to some degree, broke the fetters of the Soviet Union Socialist Model and propelled each Communist Party in Europe to explore their specific socialist road, but this theory, to a large extent, deviated from the theory of scientific socialism. Without grasping the essence of Marxism, it did not make a scientific analysis of the contemporary situation of both capitalism and socialism to reach a full understanding of its developmental stages, so a rapidt decline is inevitable.

Secondly, "Eurocommunism" intends to weaken the effect of ideology but loses its basic characteristics. 
"Eurocommunism" makes every effort to lessen the ideological colour in its theory, throwing away completely the revolutionary claims with obvious radicalism and appearing before the public as a mild political party. The reformed theory of "New Communism" still holds "Communism" as its objective, claims to "overstep capitalism", and even emphasizes frequently the differences between the Communist Party and the Democratic Party, but its essence of theory is obviously sociodemocracy-oriented, that is, to carry out a policy of limited legal reform within the framework of capitalism.

This theory breaks from the traditional radical socialist revolution, and to some extent, it is beneficial for every Communist Party, because it makes them shade off the Soviet Union Model and get more election votes. But on the other hand, this break makes the Communist Party depart from its usual unique thought of ideology. Some wstern scholars think that the contemporary Communist Party is sewn up by the pieces of ideology with different colours. As a matter of fact, the upsurge and development of European Communist Party after World War II is, in a sense, based on its unique stand and specific claim. Nowadays whether the "New Communism" can survive in the surroundings of the left-wing Parties like Sociodemocratic Party and Socialist Party, and whether they can win the wide social support, really put forward a serious issue.

Thirdly, the theoretical claims of "Eurocommunism" influenced the International Communism Movement a great deal. European Communists claimed to be exploratory, innovative and creative and emphasized the importance of democracy, freedom and human rights, which appealed to the countries of European Communist Parties who had been long confined by dogmatism. Because it aroused the desire of people for the reform of thought and the creativity of theory, it broke away from the official control and had a foothold in the East Russia and took it as its spreading market. Being the pioneer of the revolution of East Russia, "Eurocommunism" made the achievement of socialism lose weight first in Germany, the hometown of Marx, and then in Russia, the hometown of Lenin, and so finally the International Communism Movement was frustrated greatly.

\section{Conclusion}

To sum up, the theoretical and practical exploration of "Eurocommunism" influenced the world sociolist movement in history. However, from the perspective of practical effect, "Eurocommunism" had a short duration and a slight significance for various reasons. But the issues it proposed remain to be the major themes for those Communist Parties of the developed capitalist countries after the East Russia Revolution. To a certain degree, not knowing of the "Eurocommunism" in the 1970s and 1980s, we cannot completely and accurately understand the "New Socialism" in the $1990 \mathrm{~s}$ in the developed European countries, not to mention its direction and future in the $21^{\text {st }}$ century. To analyze the logical relationships of these theories, to observe the differences between them, and to see the different social circumstances the countries confront, provide us a complete understading of the history and present of the Communist Parties of the developed Capitalist countries in Europe.

\section{References}

[1] Carrillo, Santiago. "Eurocommunism" and State. Beijing: Bussiness Press, 1982.

[2] Wilson, Frank. The Failure of Western Eurocommunism. New York: Paragon, 1993. 